\title{
Jomo Kenyatta's Speeches and the Construction of the Identities of a Nationalist Leader in Kenya
}

\author{
Steve M. Mutie ${ }^{1}$, Antony Somba Mang'oka ${ }^{2}$, Bernard Chemwei $^{3} \&$ Nelly Nzula Kitonga ${ }^{4}$ \\ ${ }^{1}$ Department of Literature, Languages and Linguistics, Egerton University, Njoro, Kenya \\ ${ }^{2}$ Department of Arts, Kabarak University, Nakuru, Kenya \\ ${ }^{3}$ Department of Education, Kabarak University, Nakuru, Kenya \\ ${ }^{4}$ Department of Languages and Humanities; Garissa University College, Garissa, Kenya \\ Correspondence: Bernard Chemwei, School of Education, Kabarak University, Kenya. E-mail: \\ bchemwei@yahoo.com
}

\author{
Received: October 22, 2014 Accepted: February 20, 2015 Online Published: May 31, 2015 \\ doi:10.5539/ells.v5n2p53 URL: http://dx.doi.org/10.5539/ells.v5n2p53
}

\begin{abstract}
This paper discusses the speeches of the late Jomo Kenyatta, founding President of the Republic of Kenya. It focuses on one of the books that Kenyatta wrote Suffering without Bitterness and interrogates how he uses this literary text to navigate against the prevailing representations of him to construct his identities that portray him as a nationalist leader. The paper proceeds from the understanding that literature envoices the human person and subjectivises him. It constitutes an ideal arena for the subject's intense mental work and of his revealing of himself to the world. This paper argues that it is in Kenyatta's text that he constructs his identities. Suffering without Bitterness contains a great deal of knowledge regarding Kenyatta's character insofar as it applies to the contemporary Kenyan reality. In particular, this paper argues that from Suffering without Bitterness we acquire a great deal of knowledge concerning the processes of Kenyatta's identity formation insofar as it relates to the way he constructs his sense of self and relate it to his circumstances. It will be recalled that it is primarily on the basis of the frames of reference that we possess as individuals, or authors, that we are able to asses and make sense out of our circumstances. We construct our identities on the basis of our differential relationships with one another, on the basis of which we delineate a "space" that possesses attributes that are different from all other entities in the universe and are, therefore, unique.
\end{abstract}

Keywords: identity, nationalist leader, Jomo Kenyatta, speeches

\section{Introduction}

The African nationalist leaders of the anti-colonial struggle who acquired positions of political prominence after independence, and especially those who became the (first) presidents of the new nations played a crucial role in moulding the nation's character. Although attention has been paid to these leaders, this has been done in a manner that has somehow stereotyped them as figures whose very way of coming onto the historical scene put severe limitations on their vision and their actions. It has thus been pointed out that, in most cases, decolonisation gave power "not to revolutionary vanguards but to the national bourgeoisie poised for reintegration into subordinate positions within the imperialist structure" (Ahmad, 1992, p. 28). The bourgeoisie failed to transform social structures in the interests of the people. What accounts for this failure is supposedly the fact that the national elites, who received colonial education, fought for independence in a state of confusion because their mentality remained deeply dependent and derivative (Chrisman, 1995). Stereotypes, however, generate limitations of their own with respect to the richness of knowledge that can be garnered if we were to approach these leaders as concrete, individual human beings with a complexity of character that is intrinsic to the human person. This paper argues that such an approach can be sustained by turning our attention to one particularly promising aspect of the personality of the nationalist leaders - that of writers, which is what many of them were; and by examining the literature that they produced. This paper examines the way Suffering Without Bitterness (herein after Suffering) constructs Kenyatta's identities that portray him as a father of a nation in various ways against the backdrop of the prevailing representations of him as a land grabber, dictator and a shameless manipulator of ethnic sentiment (Muigai, 2004). 


\section{Textual Construction of an Imagined Father of the Nation}

After Kenya attained independence, the most pressing challenge that lay ahead was in making a nation out of the past. There was need to mould a unified nation out of the multiplicities of ethnicities, races and regions that formed the post-independent Kenya. Kenya's colonial economy had been moulded into a distinctive pattern by the long years of colonial rule. It displayed characteristics typical of an underdeveloped economy at the periphery: the preponderance of foreign capital, the dominance of agriculture, the limited development of industry and the heavy reliance on export of primary products and imports of capital and manufactured consumer goods. This underdeveloped state of the economy meant that independent Kenya would have to formulate policies that would not only arrest Kenya's mounting poverty but also put the economy into the hands of the indigenous people. To meet these changes, Kenyans would have to work hard to improve on existing infrastructural facilities, such as communications, health care, energy supply, educational and financial institutions (Turnabull, 1962, p. 56; Mbato, 1969, p. 234; Ogot, 1996, p. 96).

Leaders in the independent Kenya had a direct responsibility of addressing the problem of the import-oriented economy, by reversing it to an export-oriented economy. Most of what was produced in Kenya during the colonial period benefited the Empire (Maloba, 1996, p. 23). The task of the Uhuru government was therefore to formulate policies that would ensure that the citizens of Kenya had the greatest share of the subsequent development. Eventually, the achievement of independence brought vital political decisions under the control of the indigenous bourgeoisie. It also enabled some leaders to make important decisions that have shaped much of the post-independent Kenya (Ogot, 1996, p. 98).

Africanisation, in particular, was one of the most emotive political slogans in the tumult before independence and Kenyatta's promise to the people. As we have already seen, before independence, large-scale agriculture, industry and commerce were dominated by non-Kenyans. Europeans controlled agriculture and industry, while commerce and trade were dominated by Asians (Osolo, 1968, p. 184). Thus, after independence, one of the most pressing problems was to break the foreigners' dominance of the Kenyan economy and transfer it to Kenyans. In addition, due to the fact that the land issue had been at the root of most of Kenya's political troubles, it was necessary to find solutions to it in the interest of stability and growth in the post-independence era. The issue of land was the most sensitive item in the nationalist agenda. After independence, the Kenya African National Union (KANU) government had to tackle the land issue by resettling the landless on land previously owned by Europeans (Kaggia, 1975, p. 5).

In a bid to deal with these issues, the Kenyatta government came up with the Sessional Paper No. 10 of 1965 which, among other things, contends: "The state has an obligation to ensure equal opportunities to all its citizens, eliminate exploitation and discrimination, and provide needed social services such as education, medical care and social security" (Ogot, 1996, p. 12). Every country that has moved from colonialism to independence has sought to transform its inherited colonial institutions to serve the culture, needs and aspirations of the newly independent society. In Kenya, the desire for this transformation was often identified with the call for nation-building. Nation-building required that leaders define immediate and finite ends besides devising means to those ends. Kenyatta and his ruling elite preserved what they most needed from the colonial state, and particularly the law and order aspects. Institutions such as the provincial administration, the police and the army were taken over without any changes. Surprisingly, Kenyatta retained the services of European officers (Ogot, 1996, p. 93). Kenyatta's call to forgive and forget became the keynote of his government. Youth-wingers and radical nationalists who spoke of revenge were roundly rebuked. In the course of colonization, it had become increasingly clear that the colonial system was designed primarily to exploit the local resources (both material and human) for the sake of advancing the exclusive interests of the Empire. The incoming political elite largely inherited the former colonial institutions. They did not change the constitutional structures, and their relationship with the masses was bad. A new national bourgeoisie emerged and replaced the old colonial one, but the material conditions for the majority of people did not improve and in fact got worse (Fanon, 1967; Lazarus, 2004; Sivanandan, 2004, p. 46).

While direct colonial domination had been defeated, very few of the other promises of independence were realized. In fact, independence marked the beginning of economic decline, continued neo-colonialist practices and political instability. A series of brutal dictatorial governments were initiated by none other than Kenyatta, the national hero of independence who in many ways embodied both the hope of liberation and the brutal reality behind the rhetoric of freedom. As Neil Lazarus observes, "Independence seems to have brought neither peace nor prosperity to Africa. Instead, it has paradoxically borne witness to stagnation, elitism, and class domination, and to the intensifying structural dependence-economic, political, cultural, and ideological-of Africa upon the imperial Western powers" (2004, p. 45). Thus Kenyan independence failed to live up to its promises and marked 
the beginning of increasing disillusionment as it became clear to many Kenyans that nothing had changed. Domination and exploitation simply continued under a different name, culminating to the famous class conflict cited by Carl max.

Once independence from direct British colonial domination had been secured, the very different interests of many of those who had fought together against colonialism became increasingly apparent. In the mass struggles which were necessary to overthrow colonialism, a wide array of people and groups were united with the single purpose of fighting colonialism in a way that created an image of a united movement which did not take into account the dissension within it. As Lazarus (2004) points out, "the general rhetoric of anti-colonialism was reductive. It implied that there was only one struggle to be waged, and it was a negative one: a struggle against colonialism, not a struggle for anything specific" (p. 46). As a result, as already noted, once colonialism was defeated, a new national bourgeoisie emerged who simply replaced the old colonial government without making any actual change to the existing social structures.

In his influential essay "The Pitfalls of National Consciousness", Fanon (1965, pp. 148-206) describes this process, in fact predicting in advance, that while nationalism unites people in the anti-colonial struggle, once this struggle is over, its end result is simply to establish and in a sense "liberate" the national bourgeoisie who has been kept down by colonial domination. Divisions become apparent in those who united in the anti-colonial struggle, as it becomes clear that the interests of the new bourgeoisie are not in the least compatible with those of the masses. In the words of Fanon, "the national bourgeoisie steps into the shoes of the former European settlement[...]its mission has nothing to do with transforming the nation; it consists prosaically of being the transmission line between the nation and a capitalism, rampant though camouflaged, which today puts on the masque of neo-colonialism" (p. 180). What becomes apparent is that all that has been won through the anti-colonial struggle is a new national bourgeoisie which is no different than any preceding bourgeoisie.

The national liberation struggle successfully overthrew the colonial government and in its place installed a new indigenous ruling class whose interests as a class were more closely tied with those of the ruling classes of the former colonial powers than with those of the citizens. In the words of Lazarus, "In short, independence let loose the national bourgeoisie to behave as it would, like any bourgeoisie" (2004, p. 55). Hope thus led to disillusionment as it became apparent that independence did not mean change for the majority of people but simply a transfer of power and wealth into the hands of a new ruling class.

In the first few years of independence, Jomo Kenyatta was accused of betraying the masses on the grounds that he did not distribute the land to the landless and that he had become a dictator, an opportunist and a shameless manipulator of ethnic sentiments (Osolo, 1968, p. 234; Muigai, 2004, p. 189). Besides, he was accused by the colonial administrators of being a trouble maker and an evil leader: "a leader unto darkness and death" (p. 113). These representations endangered his power, which he had to retain because he had strongly fought for it. To resolve this identity problem, Kenyatta wrote Suffering without Bitterness, to construct images of himself that were meant to present him as a nationalist leader. In the book, he masks his true identity and interests in order to retain power. Kenyatta's collections of speeches serve the purpose of self-explication, clarification, presentation and justification. The book enables him to deconstruct the prevailing representations of him at the same time as they justify the reasons as to why the post-independence Kenyan society did not realize an all-round development under his leadership.

\subsection{Ethnicity Question}

In the speeches, Kenyatta imagines himself as a father of the Kenyan nation, and as such, aims to portray himself as a unifier. Being a unifier would help Kenyatta later monopolise the state power. A unifying identity in Kenyatta seems to have been inevitably invoked by the travails of tribalism, ethnicity and other divisive social evils. Since independence, tribalism and ethnic-based political parties were indicative of the failure of national politics in Kenya. There was largely lack of a sense of unity when the ethnic calculus was employed in the use of national assets and opportunities, and those not included opted for sectional identification as a sure source of strength and safety (Kaggia, 1975, p. 3). Kenyatta, for his part, had to put on the garment of a unifier leader, one who hated tribalism, disunity and other divisive policies. In his 1964 "Kenyatta Day Speech" (pp. 240-245), he railed against leaders whom he claimed were using tribalism to bring division among the Kenyan people, including the leaders of the Kenya African Democratic Union (KADU) and the African People's Party (APP). He writes: "My government rejects this and will not permit exploitation of tribalism and divisive politics" (p. 241). In saying this, Kenyatta is driven by the desire to depict the true character of a head of the state in order to ward off the increasing claims that he was a budding dictator and ethnic chauvinist. A close examination of the speech in relation to the prevailing circumstances reveals that it was a part of his strategy to disguise who he 
really was. In the speech, Kenyatta writes:

There have been murmurs here in Kenya about the part played by one set of people, or another set of people, in the struggle for uhuru [...] there has been vindictive comment, and a finger of scorn has been pointed at some selected race, or group or tribe. All this is unworthy of our future here. (p. 241)

Here, he creates the impression that he is a leader for all Kenyans. However, in the speech "Kenyatta Day of 1967" (pp. 341-348), Kenyatta poses a question to his audience which sheds light on who he really was: "where did you fight? How many weapons did you use? How many guns? [...] apart from Achieng who was with us in Lokitaung, and maybe Kaggia [...] they did nothing." (p. 343). In other words, the leaders of Kenya Peoples' Union were cowards who never fought for independence. To put it differently, Kenyatta insinuated that there are leaders who never fought for independence and who therefore they had no right to question his actions. This speech polarised the country in two opposing sides based on who fought and who didn't fight for independence. The KPU members, who were majority Luo, were thus judged as cowards who never fought for independence and thus should always remain in political cold.

In fact, in the same speech, "Kenyatta Day, 1967" (pp. 341-348), Kenyatta urges his audience to "crush the snakes" (snakes here meaning KPU members) (p. 343). Yet, as critics have shown, these KPU leaders were agitating for the eradication of poverty, equal distribution of resources, and eradication of landlessness (Ogot, 1996; Mbato, 1969: Osolo, 1968). Kenyatta's negative response to their demands therefore portrays a leader who could not listen to any opinion contrary to his. The speech shows Kenyatta's budding dictatorial tendencies.

Faced with the twin problem of forging a nation from the diverse ethnic communities of Kenya and placating the Kikuyu masses (Tamarkin, 1978, p. 298), Kenyatta decided to pursue both goals simultaneously. He co-opted the power elite of other ethnic nationalities into his ruling coalition and by so doing, he set himself up as the ultimate patron in the neo-patrimonial state he presided over, without placating the poor and the dispossessed. This complex client-patron network within which Kenyatta set up "ethnic chiefs" was aimed at helping him retain power (Muigai, 2004, p. 209). On the other hand, to mollify the Kikuyu masses, he chose to surround himself with an inner circle of Kikuyu advisors creating a kikuyu government within the government. Muigai, (2004, p. 209) observes that by choosing to champion the deep-seated land and power grievances of the Kikuyu, he was perceived as having consented to be the Kikuyu paramount chief. This strategy did not resolve the issue of historical ethnic claims.

Another mask that Kenyatta used to hide his true identity was the rhetoric of patriotism and nationalism. On the surface, he preached continuously about the need for Kenyans to rise above their ethnic and regional boundaries in order to forge ahead as a united nation. But beneath the rhetoric appears to have been a systematic programme of "Kikuyunization" of national institutions and resources.

When Kenyatta became Prime Minister in June 1963, he promised to fight poverty, ignorance and disease as a way of leading the country toward the realization of an all-round development. This, as Kenyatta put it, would be achieved through the spirit of nation-building and Africanisation of agriculture and the civil service. In his Independence Day Speech of 1963 (pp. 212-217), he averred that independence was, to the Kenyan people, the turning point of their lives, the reversal of all things in their favour. In this speech, he proposed the socialist slogan "Harambee" as a call towards self-sufficiency. The slogan was given to Kenyan workers for the purpose of national development. Kenyatta likened the task ahead of the new nation to that of workers with a burden which would only be overcome by working together to successfully heave up or put together their heavy load.

In "Kenyatta Day, 1964" (pp. 240-245), Kenyatta describes the political hurdles that he encountered in the fight for the emancipation of the Kenyan people. He presents himself as a leader who suffered as a sacrifice for the nation. He narrates to his people the difficulties he experienced in founding the nation, presenting himself as a nationalist who endured and came out of suffering victoriously. He prides himself in fighting for the welfare of the Kenyan people, recalling how he was "heavily chained in detention camps and prison [but how] he never gave up" (p. 243). He knew that "one must learn to suffer and endure, to replant or rebuild, to move on again. In his view, "a practitioner must never lose faith" (p. 6). By presenting these actions, Kenyatta aims to be understood as a patriotic leader who is concerned with the welfare of his nation.

It would appear that what Kenyatta was calling nationalisation was indeed the "Kikuyunization" of Kenya and what he was calling nationalism was the ongoing protection of his political and economic interests. Although he continued to talk of Kenya as one nation and to de-emphasize ethnicity in its public statements and policies in land, service delivery and jobs, the unifying rhetoric of nationhood concealed a less palatable truth. The 1960s saw the entrenchment of Kikuyu power via a web of both formal and informal networks. The senior civil service was increasingly dominated by the Kikuyu (Ogot, 1996, p. 95). The crucial posts of provincial commissioners, for 
example, were held by a small group of conservative insiders, more than half of whom were Kikuyu from 1964 until Kenyatta's death, and three of whom were sons of chiefs. Appointments to statutory boards and Parastatals replicated the same trend (Attwood, 1967; Osolo, 1968; Mbato, 1969; Ogot, 1996). For instance, Osolo, (1968) notes that:

In most of the key positions throughout Kenya's major infrastructural developments, one found members of Kenyatta's tribe (Kikuyu). What is perhaps most important to note is that, since independence nearly all key cabinet ministries (Finance, Defence, Foreign Affairs, State, Attorney General and Land and Settlement) were held by a group of members of Kenyatta's tribe; Mungai Njoroge (Kenyatta's relative through marriage), Sir Charles Njonjo (Attorney general from Kenyatta's district) inter alia. (p. 234)

A further examination of who was who in Kenyan economic sector in the early 1960's shows that the Kenyan political economy, both political and economic were controlled by Kenyatta, Kenyatta's wife (Ngina), Mungai Njoroge, Sir Charles Njonjo inter alias.

It is important to note that Kenyan tribalism is a relatively new phenomenon. Basically, it is a product of modernity, arising from colonialism, urbanization and the political culture that sprung up in the course of colonization (Ahmad, 1992, p. 22; Legum, 1999, p. 84; Amin, 1997, p. 93). Before the coming of the colonialists, Kenyan tribes lived in their own distinct areas with their own cultures, i.e. language, customs, myths of origin, etc. The communities lived free from each other, save for some conflict over water and pasture for livestock. Essentially, tribalism was born when the colonial government haphazardly incorporated the various ethnicities and regions with the boundaries of the relatively new nation-state that came to be known as "Kenya." Tribalism is closely connected to the management and distribution of the available national resources. It arises when individuals are alienated from the centre of power or otherwise discriminated against on the basis of their ethnic affiliation. Oftentimes, this happens when one ethnic group or an alliance of ethnic groups utilizes the institutions of the state to monopolise national politics and state resources at the expense of other ethnic groups (Tarimo, 2008, pp. 2-5).

The colonialists magnified differences amongst the various communities / tribes instigating clashes whereby each community distrusted and fought each other. This served as the breeding ground for negative tribal stereotypes which then became embedded in popular belief. Tarimo (2008, p. 2) argues that the Kikuyu, for example, were given the impression that the fish-eating Luos were lazy, uncircumcised and unreliable while the Luhya's were made to view the GEMA communities as schemers, liars, untrustworthy, arrogant and so forth. This situation of suspicion persisted till the time when independence was realized in 1963. At this point, tribal suspicions shot up as the two major parties KADU (Kenya African Democratic Union) and KANU (Kenya African National Union) began squabbling over power. KANU was a party largely dominated by two tribes: the Kikuyu and the Luo. KADU, on the other hand, was a coalition of all the other small Kenyan tribes that feared being dominated by the Kikuyu-Luo alliance under KANU (Ogot, 1996, p. 49).

After independence and the granting of independence to KANU, the unity between the Luo's and the Kikuyu's was short lived. Instantaneously, Kenyatta (a Kikuyu) became President and his administration started favouring the Kikuyu people. This favouritism manifested itself in greater government expenditures for social infrastructure in Kikuyu areas, corruption benefits to fellow tribesmen and privileged access to government and parastatal jobs (Ogot, 1996, p. 49). The Luo, on the other hand, despite holding the vice presidency, were largely discriminated against and their complaints only elicited intimidation and even assassinations in return. Under the Jomo Kenyatta government, it was common to have many under-qualified staff from the Kikuyu community placed in positions of higher authority than the qualified ones from other tribes (Tarimo, 2008: 3). This led to the final falling out between the Luo and the Kikuyu in the government as the Vice President, Oginga (a Luo), was eventually pushed out of government and detained (Tarimo, 2008, p. 3). The tribal rift was widened and solidified when a Luo minister, Tom Mboya, who had remained in government, was assassinated in 1969. The assassination was blamed on highly placed Kikuyu politicians, and this was seen as an assault on the Luo by the Kikuyu, and since then Kenyan politics has essentially pitted the Kikuyu against the Luo (Ogot, 1996, p. 54). As each of the two tribes attempted to attract other tribal groups to its side, Kenyatta sought to reshape and save his face by projecting an image of himself as a non-tribal chief.

In this respect, perhaps Kenyatta's most important response against the increasing perception that he was a tribalist were his speeches, especially the ones that were included in Suffering. In speech after speech, he sought to remind his listeners about the dangers that the division of Kenya along tribal lines posed to the country's future. It will be recalled that at the beginning of his presidency he had cautioned Kenyans that unless they achieved national unity they could become vulnerable to the same forces of imperialism and colonialism that had 
created their present conditions (Osolo, 1968, p. 25; Mbato, 1969, p. 3). In his verbal addresses to the nation in the course of the 1960s, especially subsequent to the fall-out with Odinga, he repeatedly emphasized that message. But it is debatable whether or not he achieved the objective of creating a more palatable image of himself as far as his handling of ethnic relations are concerned. The reason, as we will see in due course, was because criticisms of him to that effect persisted in spite of the patriotism he repeatedly communicated to the nation and to the world.

One of the speeches in which Kenyatta sought to exonerate himself from accusations of negative ethnicity is the one entitled "Dissident Activity, 1966" (pp. 302-307). One of the most confounding challenges that the newly independent Kenya faced at the dawn of independence was how to formulate the most appropriate ideology in view of its developmental objectives. There were two conflicting directions that Kenya could follow at the time, and the determinant factor was the on-going Cold War on the one hand, there was the Western Block of Nations led by the United States of America (Ahmad, 1992, p. 22). On the other, there was the Eastern Block of Nations led by the former Union of Soviet Socialist Republics (USSR). The West sought to spread the capitalist ideology within the context of the so-called liberal democratic political environment. The East championed the communist ideology as espoused by Carl Marx (Wallerstein, 1996, pp. 34-35).

Each Block of nations sought to spread its ideology throughout the globe. As a result, most countries around the world, especially weak countries like Kenya, were forced to choose between the two sides. This led to conflicts in various places in the world as communities organised themselves either in line with the capitalist or the communist ideology. Most of the coups and the counter-coups that characterised the 1960s and 1970s were, in one way or another, related to the influence of the two competing sides. In Africa, for example, the struggle for independence in Mozambique, Angola and Ethiopia pitched capitalist against communist or socialist forces (Wallerstein, 1996, pp. 34-35).

Scott (1997, pp. 9-10) observes that in response to Cold War and the adverse influence that it had on the developing world, underdeveloped countries organised themselves under the umbrella of the Non-Aligned movement. The reason was because they wanted to avoid being caught up in the proxy wars that were being fought around the world on behalf of the West and the Soviet Union. It is within this context that the type of capitalism that Kenya under Kenyatta pursued will be understood.

Through the concept of "African Socialism", Kenya represented itself to the world as a distinct nation that was not necessarily Western-oriented. In this respect, Kenya aligned itself with the Non-Aligned movement. But in fact Kenya was a capitalist country which was firmly in the armpit of Western Capitalism. Kenya was important to the West because it played a strategic role in East Africa as a bulwark against communism, especially so because certain countries in the region, including Tanzania under Nyerere and Uganda under Milton Obote were experimenting with socialism. To reinforce this position, the West provided the country with considerable financial and material support in exchange for the critical role that it played in the Cold War on behalf of the West.

One of the reasons why Kenyatta fell out with Odinga was because of the emerging impression that Odinga was sympathetic toward the communist Block of Nations. In the course of the 1960s there was increasing criticism toward Odinga to the effects that he represented the interests of the Soviet Union in Kenya and that his intention was to overthrow the capitalist regime and replace it with a communist one. These impressions were reinforced by the decision by the Soviet Union to provide funds to build major hospital in Kisumu. Kenyatta took advantage of these accusations against Odinga to engineer his exclusion from the government together with his Luo people, who constituted KPU.

From a close study of the speech "Dissident Activity, 1966" (pp. 302-307), it is clear that the basis of Kenyatta's criticisms of Odinga in this respect was not so much his communism inclinations as his Luo background. The argument that Odinga was a communist whose primary objective was to overthrow the capitalist system is contradicted by the facts on the ground. In his autobiography Not Yet Uhuru, Odinga describes himself as a nationalist whose primary objective is to advance "African Socialism" which within the Kenyan context is by no means communism (1966, p. 54).

Furthermore, Bildad Kaggia observes that the foundation of KPU was to realise the equitable redistribution of resources among Kenyans by bridging the gap between the rich and the poor, which does not necessarily imply imposing communism upon Kenya $(1975$, p. 76$)$. Yet in the speech, Kenyatta distances himself from Odinga primarily on the grounds that he is a communist. He argues that the members of the KPU were paid agents of the Soviet Union. He insists that in so far as the requirement of the common mwananchi is concerned, the communist system is utterly inadequate. He observes that "it is a sad mistake to think that you can get more food, 
more hospitals or schools by simply crying communism" (p. 243).

But if, as we have seen, Odinga was not a communist, then what exactly was the basis from which Kenyatta was criticising him in that respect? In view of the ethnic equation that was driving politics in Kenya at the time, one cannot help but conclude that Kenyatta's problem with Odinga was because the latter symbolised the interests of the ethnic groups that were affiliated to KPU, of which the Luo were the most dominant.

The same point can be made with regard to the speech "Constitutional Conference, 1963" (pp. 209-211). The purpose of the speech is to re-assure the various ethnicities that constituted the New Kenya at the time, including the European former colonisers and the Asian Community, in regard to the country's future potential. But a close paper of the speech in light of what we already know about his true ideological orientation makes one wonder whether he was genuine in that regard. It would appear that the primary motivation behind these reassurances was the need for him to establish an alliance between the emerging African elite and the former colonizers in order to safeguard the economic interests of the ruling class.

At independence, the African community, in spite of its numerical majority, did not possess the skills that the country required in order for it to forge ahead as quickly as possible in terms of development (Osolo, 1968, p. 25; Mbato, 1969, p. 3). The former European colonisers and to a lesser extend the Asian community, monopolised the skills that the country needed in the civil service, the military, the police, and the administration. Kenyatta's challenge was how to transfer these skills to the local elite without alienating the former colonial masters. He wanted to retain them in the country long enough for the new African elite to master those skills enough to advance the interests of the country on their own (Odhiambo, 1976)). The speech provided a powerful medium through which he pursued that objective.

Perhaps the most important points that Kenyatta advances in the speech is the idea that Kenyans should not dwell on the past but should move together into the future in unity and fraternity. He assures the former colonizers that his government would not avenge itself against them for whatever injustices they may have committed against the natives in the course of colonialism. In addition, he requested the native African citizens to focus on the future rather than on the past.

In this connection, their primary pre-occupation should be to strive to realise their dreams, both in their individual and their collective capacities through hard work. This was because work constituted the most important context through which they would liberate themselves as individuals and as a country.

To put it differently, it was not necessarily the call to nationalism that compelled Kenyatta to forgive and forget the past. Rather, it was the desire on his part to forge an alliance between the emerging African elite that he represented and the former colonisers who possessed the critical skills that the new elite so desperately needed in order to achieve their collective aspirations.

The same concerns about unity appear in the speech "Jamhuri Day, 1965" (pp. 294-297). But here again, one wonders about the true motivations behind the President's call for unity. He utilizes biblical imagery to construct the vision of Kenya that he desires for the country. He argues that it is only through unity and a common purpose that the people of Kenya will reach Canaan. But it will be recalled that at the time that he was making this speech it was commonsensical across Kenya that he was effectively establishing a foundation for Kikuyu hegemony (Osolo, 1968: 25; Mbato, 1969: 3). Furthermore, he gave the speech shortly before he fell out with Odinga, the precursor to the exclusion of the Luo community from the centre of power.

\subsection{The Land Question}

So far, we have examined the strategies that Kenyatta utilised to mask his ethnic and capitalist inclinations. We have seen that his call for unity and inclusion across ethnic and racial boundaries was in fact a camouflage for his commitment to the emerging, largely ethnic elite, for the most part at the expense of the majority of the people. The same argument can be made with respect to the manner in which he handled the issue of land in the immediate post- independence period. It has been argued that Kenyatta took advantage of his position as the President to amass large quantities of land for himself and his family (Attwood, 1967, p. 23; Osolo, 1969, p. 237; Ogot, 1996, p. 97; Kipchumba, 2008, p. 1). A close examination of the speeches contained in Suffering indicates that they provided a powerful medium through which he camouflaged this form of abuse of power.

In the speech "Back to the Land, 1964" (pp. 232-235), Kenyatta urges citizens to make use of their lands for economic advancement. He reminds them that land is the best resource which every citizen could use to advance himself and the society. In the speech, Kenyatta discourages people from loitering and laziness reminding them that "the time for slogans and empty words has come to an end. We cannot cry for more land, and yet fail to develop that which we have" (p. 234). Kenyatta here implies that the landless were not justified in their quest for 
land. According to him, they did not deserve their ancestral land back since they could not manage it. He downplays the fact that the people who found themselves landless at the dawn of independence had their land alienated from them by the European settlers.

Land alienation originated from the confiscation of land from the indigenous people by British settlers. These indigenous people hoped that they would be given back their land after independence but unfortunately, this land was, after independence retaken by politically powerful personalities. Ogot (1996, p. 98) argues that Kenyatta and his associates benefited from the land left behind by the White settlers relegating those who owned the land before the white settlers to the category of the landless.

Tarimo (2008) argues that as many settlers were returning to Britain, Kenyatta and his cronies quickly formed the Settlement Transfer Fund Schemes (STFS) and asked the British for a loan to the Kenyan government to buy off land from colonial settlers returning to Britain. She explains that this idea was noble and that Britain advanced the money because it was assured by Kenyatta that those settlers still wishing to stay on in Kenya would not have their land repossessed. This money was used to buy settler land that was officially sold into the Kenyatta initiated STFS. This is the point at which the rain started beating Kenya. Kenyatta's then Vice President, Oginga Odinga, cried foul and rejected these acts of "reckless land grabbing" (Tarimo, 2008, p. 3).

The speech "Kenyatta day, 1967" (pp. 340-348) is particularly a response to Odinga's criticism. In the speech, Kenyatta blames Odinga and the KPU members for sabotaging the government activities. He dismisses KPU for not fighting for freedom and threatens them: "KPU should beware! The fighting for our uhuru is on. Whoever has ears to hear, let him heed this. We are ready to fight for our uhuru (344). True to his word, Kenyatta, as Ogot (1996, p. 56) contends, detains Odinga and all the KPU members without trial two years after this speech. In this score, it can be argued that the representations of Kenyatta as a dictator hold truth.

Bildad Kaggia, one of the Kapenguria detainees, argued that since land issues had been the fundamental cause of the "Mau Mau" war against the British settlers in Kenya, and since in his Facing Mount Kenya and Kenya, The Land of Conflict, Kenyatta had indicated that African land and cultures were to be returned to, or left for their habitual African owners from whom the settlers usurped the land, Kenyatta was expected to honour his pledges but he does not do so. Kaggia expected that after Kenya achieved independence, those land tracks that had been taken by the European and Asian settlers would be returned to their rightful owners (Mazrui, 1970, p. 3). However, to Kaggia's surprise, no one received his land back as Kenyatta demanded that whoever wanted his land back must first of all pay for it. The rule was simple: no money, no land. Thus the possession of money was mandatory for land restoration and acquisition.

Kenyatta ridiculed and disgraced Kaggia by publicly saying:

Kaggia, we were together with Paul Ngei jailed, if you go to Ngei's farm, he has planted a lot of coffee and other crops. What have you done to yourself? If you go to Kubai's, he has a big house and a nice shamba. Kaggia, what have you done for yourself? We were together with Kung'uKarumba in jail, now he is running his own buses. What have you done for yourself? (Mazrui, 1965, p. 23).

The argument between Kenyatta and Kaggia took place in 1965, but more recent studies on the land question confirm that Kenyatta's objection to the distribution of land prevailed till his death in 1978 (Osolo, 1980, p. 43). Land which belonged to $\mathrm{X}$ before independence could only be returned to $\mathrm{X}$ after independence if $\mathrm{X}$ had the money to buy back his own land. Otherwise $\mathrm{X}$ had no right over it.

An amazing aspect of Kenyatta's political action was his demand that Africans must pay to buy land that was formally lost to white settlers. Kenyatta knew well that most of his people were too poor to buy the land without the benefit of loans and also that no one could get a loan without any substantial collateral or sound proof of ability to pay back the loan (Mazrui, 1965, p. 45). These criticisms are a significant contradiction to the promises that he made to Kenyan people in his pre-and-post-independence speeches. Kenyatta had promised that his rule would be totally different from the British rule that had excluded Africans from the political process and that had deprived them of the due process of the law. Unlike the outgoing British government, Kenyatta's government was to fling open all the doors to all Africans. He alleged that he would welcome criticism from the opposition, and individuals and concentrate on a cooperative policy arrived at the problem of nation-building. He declared that without such criticism, his ruling party could not be effective. Thus, Kenyatta had initially viewed the existence of an opposition as a healthy input to the political process in Kenya (Osolo, 1968, p. 134).

One wonders why Kenyatta had to depart from his political ideals given that he had suffered so much at the hands of undemocratic colonial rule in Kenya. An analysis of Kenyatta's activities above suggests that his departure from this earlier line of action to a different one must have been a function of his realization that he 
had already solidified his political leadership position well enough not to worry about anything. Thus, Kenyatta did not just become a revisionist; he became a deviant political theoretician highly possessed with the attractive enormous economic gains and political prestige attached to the office of the presidency. Like all his counterparts throughout the developing world, Kenyatta became so flooded with riches coming from corruptive offers from inside and outside Kenya in return to his favours to the source of such riches and offers that he would not stomach criticisms from Kaggia, Odinga and other socialism advocates (Mbato, 1969, p. 2).

There is no doubt that this must have been the reason why Kenyatta and his close associates became millionaires within a very short time. This attitude also give light to the reason why a leader like Oginga Odinga could not be allowed to continue serving as Vice President by Kenyatta. It also gives a bearing to the reasons why Kenyatta wanted the post of President to remain within his kikuyu tribe in order to protect the wealth he had already accumulated on a large scale; and why Kenyatta could not tolerate the existence and political ideals of his critics (Pegushev, 1996, p. 191).

Immediately after Kenyatta's government was installed, land policy became a bone of contention, and Kenyatta would openly express his stand on land. In the speech "Constitutional Conference, 1963" Kenyatta assured Kenyans: "I know that one of the most sensitive questions in our country is land. I now give a categorical assurance that under the Constitution, all tribal land is entrenched in the tribal authority and no one can take away land belonging to another tribe" (p. 211). Here, Kenyatta portrays himself as a strong protector of people's interests - a leader who understands the plight of his people. However, Kenyatta only protects the interests of a certain group of people. Although he talks in an inclusive manner, he only uses this kind of political rhetoric to appear relevant and therefore retain power. This kind of contradiction does not portray Kenyatta as the patriotic leader that he constructs in Suffering, it reveals a leader whose aim was to retain power using all available means.

\section{Conclusion}

This paper has noted that Kenyatta departs from the aims that propelled him to power and which he writes about in his earlier works that's Facing Mount Kenya (1938) and Kenya, The Land of Conflicts (1944). His main objectives in an overthrow of the colonial rule would have been to restore the usurped land to the rightful owners; to eradicate all forms of class distinctions and their causes; and to govern Kenya within the frameworks of Harambee, a socialist principle of all against the common enemies, i.e. hunger, poverty, ignorance and disease. Significant degree of inconsistency abounds between Kenyatta's portrayed identities and who he really was in practice. This is borne out by findings on Kenyatta who at the eve of independence gave several empty promises that he later could not honour. These include his promise that he could restore usurped land to its rightful former owners; that he was going to welcome the opposition and other government critics as essential ingredients for a healthy political process; that he was not a kikuyu leader but a national leader and therefore that all tribes were going to harvest equal shares of Kenya's independence. There is therefore no doubt that these and other Kenyatta's political actions collectively demonstrate a clear practical departure from his political theory. This is also the reason why many people during Kenyatta's leadership felt that Kenya was still "Not Yet Uhuru i.e. not yet independent."

The question of land has been a contested one since independence, and it has haunted Kenya to date. The violent reactions to allegations of rigged elections in 2007 may reflect the pain of deep and historically rooted injustices some of which pre-date Kenya's independence in 1963. To a certain extent the occasion presented a chance to correct some of the historical wrongs committed against certain communities. Injustice occurred in the area of land ownership, when land was confiscated from the indigenous people by British settlers and later retaken by politically powerful personalities after independence in 1963. Instead of returning the stolen lands to the original owners, the politically connected personalities benefited the occasion of the departing white settlers to grab land, while relegating those who owned the land before the white settlers to the category of the landless. Reactions of discontent have been revealed in the land clashes of 1992, 1997, and 2007. These clashes display the anger among those living in impoverished conditions. Others are also frustrated because of the deliberate delay in addressing certain problems haunting the society since independence.

This is a system that has continuously perpetrated, in successive fashion, socio-economic injustices that have been seamlessly transferred from one power regime to the next. However, reading Kenyatta's suffering, one would not imagine such a balanced and innocently crafted person could inculcate into a society some negative values that would gnaw deep fifty years after independence.

In recent years, the dominant ethnic groups have been on the forefront in fighting for political power. This situation has resulted into fighting to control the state. The relatively less dominant communities have been playing the card 
of opportunism. Many ethnic groups supported the armed struggle for independence in hope that they could regain their stolen lands. This expectation did not become reality. The situation has fomented anger, resentment, lust for revenge, and aggressive competitiveness that has overlooked the common good of the entire country. Frustration among the poor, both in urban and rural areas, has created a growing tendency to use violence as a viable means to correct the situation. When violent reactions emerge, under the influence of ethno-political ideologies, tend to take the form of ethnocentrism, the ideology that animates the competition between ethnic groups.

The phrase "Suffering without Bitterness" could refer to almost any deeply felt passion or political conviction. It is an expression of political desire, a theme that is picked up in the book's subtitle, "The Founding of the Kenyan nation." At the time of writing this textsome peoplewere already disillusioned by his policies but clearly Kenyatta expects them to be impressed by his political accomplishments, and to take some pride in his aspirations. Moreover, he sees his own career, not from the perspective of the rough-and-tumble of the political arena, but as a political exercise, as a process of education. He also implies that somehow he was destined to become President, as he announced his intention of telling his life story as if everything he ever said or did led directly to his assumption of the ultimate leadership role. The title thus announces that this is not going to be a story filled with random anecdotes or diverting digressions. In the "mythical rearranging of his life, Kenyatta chooses to see himself as a leader of a very special sort-as the founding father of the nation. As such, he is one who has accumulated vast knowledge, and has lived his life so as to put that knowledge at the service of the people. He thus sets out to evoke his father of the nation self as a suitable image of leadership for a people leaving colonialism behind but needing guidance for a new order.

\section{References}

Ahmad, A. (1992). In Theory: Classes, Nations and Literatures. London and New York: Verso.

Amin, S. (1997). Capitalism in the Age of Globalisation: The Management of Contemporary Society. London and New Jersey: Zed.

Attwood, W. (1975). The Reds and the Blacks, Political Economy of Neo-colonialism, 1964-1971. New York: University of California Press.

Chrisman, L. (1995). Inventing Postcolonial Theory: Polemical Observations. Pretexts, 5(1), $205-212$.

Fanon, F. (1965). The Wretched of the Earth. London: Pelican.

Fanon, F. (1967). Black Skin, White Masks. New York: Grove Press.

Kaggia, B. (1975). Roots of Freedom 1921-1963: The Autobiography of Bildad Kaggia. Nairobi: East African Publishing House.

Kenyatta, J. (1938). Facing Mount Kenya. London: Secker and Warburg.

Kenyatta, J. (1944). Kenya: The Land of Conflict. Manchester: International African Service Bureau.

Kenyatta, J. (1968). Suffering Without Bitterness. Nairobi: East Africa Publishing House.

Kipchumba, S. (2008). How State Land Policy shaped Conflict. Daily Nation, Kenya, p. 9.

Lazarus, N. (2004). The Cambridge Companion to Postcolonial Literary Studies. Cambridge: Cambridge University Press. http://dx.doi.org/10.1017/CCOL0521826942

Legume, C. (1999). Africa Since Independence. Bloomington and Indianapolis: Indiana University Press.

Maloba, W. (1996). Decolonization: A Theoretical Perspective. In B. Ogot \& W. Ochieng (Eds.), Decolonization and Independence in Kenya 1940-1993 (pp. 7-25). London: James Currey.

Mazrui, A. (1965). East African Standard. Nairobi, April 12.

Mazrui, A. (1970). The Monarchical Tendency in Africa Political Culture. In E. Marion \& M. Nawell (Eds.), Governing in Black Africa. Englewood Cliffs, NJ: Prentice Hall.

Mbato, R. (1969). Identity. Bursara, 2(3). Nairobi.

Muigai, G. (2004). Jomo Kenyatta \& the Rise of the Ethno- Nationalist State of Kenya. In B. Berman, D. Eyo \& W. Kymlicka (Eds.), Ethnicity and Democracy in Africa. London: James Currey.

Odhiambo, A. (1976). Seek Ye First the Economic Freedom: A History of the Luo Thrift and Trading Corporation (LUTATCO) 1945-56. In B. Ogot (Ed.), Hadith 6: Economic and Social Change in East Africa (pp. 168-185). Nairobi: EALB.

Odinga, O. (1967). Not Yet Uhuru. London: Heinemann. 
Ogot, B. (1996). The Construction of a National Culture. In B. Ogot \& W. Ochieng (Eds.), Decolonization and Independence in Kenya 1940-1993 (pp. 214-238). London: James Currey.

Ogot, B. (1999). Building on the Indigenous: Selected Essays, 1981-1998. Kisumu: Anyange Press.

Ogot, B., \& Zeleza, T. (1988). Kenya: The Road to Independence and After. In G. Prosser \& R. Louis (Eds.), Decolonisation and African Independence (pp. 401-426). New Haven, CT: Yale University Press.

Osolo, A. (1968). Who Controls Industry in Kenya? Nairobi: East Africa Publishing House.

Osolo, A. (1980). Objective Military Control: A New Paradigm in Civil-Military Relations. Peace Research, 17, $1-30$.

Pegushev, A. (1996). The Unknown Jomo Kenyatta. Egerton Journal, 1(2), 191-200.

Scott, C. (1999). Seeing Like a State: How Certain Schemes to Improve the Human Condition Have Failed. New Haven, CT: Yale University Press.

Sivanandan, T. (2004). Anticolonialism, National Liberation, Postcolonial Nation Formation. In N. Lazarus (Ed.), The Cambridge Companion to Postcolonial Literary Studies (pp. 41-65). Cambridge: Cambridge University Press. http://dx.doi.org/10.1017/CCOL0521826942.003

Tarimo, A. (2008). Kenya, the Common Good and the Politicization of Ethnic Identities. Nairobi: Markkula Centre for Applied Ethics Press.

Tarmakin, M. (1978). The Roots of Political Stability in Kenya. African Affairs, 77(308), 298-302.

Turnbull, C. (1962). The Lonely Africa. New York: Simon \& Schuster University Press.

Wallerstein, I. (1996). Historical Capitalism with Capitalist Civilization. London and New York: Verso.

\section{Copyrights}

Copyright for this article is retained by the author(s), with first publication rights granted to the journal.

This is an open-access article distributed under the terms and conditions of the Creative Commons Attribution license (http://creativecommons.org/licenses/by/3.0/). 